\title{
Opinião
}

\section{INSTRUMENTO DE AVALIAÇÃO PSICOLÓGICA: UMA PRIMEIRA VERSÃO}

Fausto Eduardo Menon Pinto (1)

Nos últimos anos, vêm-se fomentando uma série de estudos preliminares (Pinto, F. E. M., 2008, 2009), no campo da Psicologia Básica, no sentido de elaborar uma compreensão de sujeito psicológico, que seja entendido pela interligação complexa de diversas dimensões psíquicas. A cognição e a afetividade são dimensões que tendem a influenciarem significativamente os relacionamentos afetivo-sociais. Para essa concepção, o ser humano não é apenas um ser racional, que constrói relações lógicas entre a sua realidade externa e interna, tampouco um ser apenas emotivo, com seus inúmeros sentimentos e estados de ânimo. Mas, a somatória dinâmica dessas duas dimensões; porquanto, um ser cognitivo-afetivo. Nessa suposição teórica, especialmente na área clínico-hospitalar, sugere-se a elaboração de um instrumental sintético de avaliação psicológica (TRZEPACK, P. T.; BAKER, R. W.,2001).

Pretende-se auxiliar os profissionais da saúde mental na elucidação e na evolução do quadro clínico do paciente. Para a produção do mesmo, optou-se por descrever três aspectos multidimensionais do sujeito psicológico, que abrangem a cognição, a afetividade e os relacionamentos afetivo-sociais. Explicando melhor os três descritores, pelo termo cognição, entendese a dimensão psíquica referente aos processos do pensamento e de seus correlatos. Todo o processo envolvido no ato de pensar, julgar ou raciocinar, representado por categorias como a percepção e a memória, por exemplo.

Nesse sentido, uma pessoa ao usar a sua dimensão cognitiva está descrevendo o quê, de que forma e como pensa. Por afetividade, por sua vez, entende-se o conjunto de emoções e sentimentos. Emoção significa as infinitas alterações que acontecem no corpo, quando se está surpreso, apaixonado ou com raiva de alguém. 
Os sentimentos denotam a alteração que acontece em nível cognitivo em cada ser humano. Seria, o significado em palavras da experiência emocional. É o colorido das mais variadas experiências vividas pelo ser humano. Nesse apêndice dos afetos, deve-se estar muito atento à frequiência e intensidade de um grupo específico de sentimentos, pois há doenças conhecidas como transtornos de humor.

No assim intitulado humor depressivo, o ser humano perde completamente o interesse e prazer pelas tarefas corriqueiras, a auto-estima fica em baixa, surgem dificuldades de concentração, sentimentos de apatia, desânimo e sensação de fracasso persistente, além de alterações no sono e no apetite. Outras alterações como, dificuldade em tomar decisões, impaciência, chorar à toa e sentimentos de culpa. Por último, nos relacionamentos afetivo-sociais, tem-se a qualidade em que o ser humano se agrega psicologicamente a outrem. Quer seja na família, quer seja no convívio social. Nessa mesma classificação, existe uma análise muito pertinente alusiva à maneira pela qual a pessoa se vê, ou melhor, a visão de si mesmo, o Self.

Apresenta-se ao (à) leitor(a), a seguir, a versão preliminar de um instrumento, que já foi aplicado, em caráter experimental, na Prefeitura Municipal de Descalvado-SP nos anos de 2006/2007.

Trata-se de uma versão em processo de teste e, que deve ser melhorada futuramente, através de pesquisas e reflexões complementares.

\section{Instrumento de avaliação psicológica - VERSÃO TESTE}

\section{Dados gerais de identificação do paciente}

Nome do Paciente/Idade:

Queixa:

Responsável pelo atendimento/Data:

\section{Cognição}




\title{
Percepção
}

\begin{tabular}{|l}
\hline Normal ( ) \\
\hline Déficit ( ) \\
\hline Ilusão ( ) \\
\hline Alucinação ( ) \\
\hline Delírio ( ) \\
\hline
\end{tabular}

\section{Atenção}

Normal ( )

Instável ( )

Superficial ( )

Dispersa ( )

Ausência ( )

Memória

Normal ( )

Alteração de fixação ( )

Alteração de evocação ( )

Déficit ( )

Amnésia ( )

Imaginação

Sucinta ( )

Excessiva ( )

Lacônica ( )

Romântica ( )

Paranóide ( )

\section{Idéias/Associação}

Normal ( )

Lenta ( )

Rápida ( )

Fuga de idéias ( )

Confusão ( )

\section{Consciência}

Normal ( )

Alteração de tempo ( )

Alteração de espaço ( )

Alteração da percepção do "eu" ( )

Ruptura ( )

\section{Afetividade}

\section{Estados afetivos}

\author{
Alegria ( ) \\ Mania ( ) \\ Irritabilidade ( ) \\ Ansiedade ( ) \\ Insegurança ( ) \\ Desesperança ( ) \\ Culpa ( ) \\ Cólera ( ) \\ Depressão ( ) \\ Apatia ( )
}




\begin{tabular}{|l|}
\hline Tristeza ( ) \\
\hline Desânimo ( ) \\
\hline Inércia ( ) \\
\hline Melancolia ( ) \\
\hline Luto ( ) \\
\hline Insatisfação ( ) \\
\hline Outro ( )- qual? \\
\hline
\end{tabular}

\section{Intra e inter-relacionamentos/Visão de si (Self)}

\section{Relacionamento afetivo}

\section{Freqüentes ( )}

Duradouros ( )

Estáveis ( )

Instáveis ( )

Retraimento afetivo ( )

\section{Relacionamento Familiar}

Há cumplicidade ( )

Há companheirismo ( )

Há confiança ( )

Há apoio ( )

Há hostilidade ( )

\section{Visão de si (Self)}

Atribui qualidades a si próprio ( )

Demonstra e devolve afeto ( )

Auto-estima rebaixada ( )

Autoconceito rebaixado ( )

Frustra-se com certa facilidade ( )

Planeja o seu futuro ( )

Satisfeito na profissão ( )

Recebe e devolve elogios ( )

Deseja e realiza ( )

Percebe o ambiente de forma hostil ("ameaçador") ( )

\section{Observações gerais do atendimento}




\section{Referências}

PINTO, F. E. M. (2008). As muitas faces da afetividade: um breve debate sobre o funcionamento psicológico do ser humano. BARBARÓI, n. 28, 75-88; PINTO, F. E. M. (2009). Quem é o sujeito psicológico? Algumas reflexões e apontamentos teóricos futuros. PSICOLOGIA.COM.PT, p. 1-19.

TRZEPACK, P. T.; BAKER, R. W. (2001). Exame psiquiátrico do estado mental. Lisboa: Climepsi.

\section{Sobre o autor:}

(1) Fausto Eduardo Menon Pinto é Psicólogo pela Universidade São Francisco, Mestre em Educação pela FE/Unicamp e Psicólogo da Prefeitura Municipal de Hortolândia/SP.

Endereço para correspondência: Rua Nova Aliança, número 164, Novo Cambuí (bairro), Campinas/São Paulo, CEP: 13.093-630.

E-mail: faustomenon@bol.com.br

Nota: O autor agradece à Professora Doutora Maria Eugênia Scatena Radomile, pela importante acolhida, desde os idos tempos de formação acadêmica, tanto em nível pessoal, quanto ainda profissional, no incentivo da implementação de algumas idéias no campo da psicologia hospitalar.

\section{Como citar este artigo (Formato ISO):}

PINTO, F.E.M. Instrumento de avaliação psicológica: Uma primeira versão. Id on Line Revista de Psicologia, Julho de 2010, vol.1, no.11, p.07-11. ISSN 1981-1189. 